\title{
The tendency for the change of yield and grain quality of spring wheat (soft and durum) in the conditions of Oren-burg Cis-Urals
}

\author{
Vitaly Skorokhodov* , Alexandr Zorov, and Yury Kaftan
}

Federal Research Centre for Biological Systems and Agricultural Technologies of the Russian Academy of Sciences, 460000, January 9 str., 29, Orenburg, Orenburg region, Russian Federation

\begin{abstract}
Grain quality is an indicator for the intensification of grain production, integrating the interaction of various agrotechnical measures and weather conditions. The purpose of this experiment is to determine the main trends in the yield and grain quality of spring durum and soft wheat in the conditions of the Orenburg Cis-Urals. The experiment was carried out in 2016-2020 at the permanent study area of the Department of Agriculture and Resource-Saving Technologies of the Federal State Budgetary Research Institution FRC BST RAS. The coordinates of the location of the test site is $55.306547^{\circ} \mathrm{E} 51.775125^{\circ} \mathrm{N}$. The study established the influence of predecessors on the quality of wheat grain. The best among them were black fallow, winter crops, maize and peas. The quality of wheat grain cultivated in permanent crops without the use of mineral fertilizers decreased. The use of green green manure as fertilizer increases the content of wet gluten up to $34.0 \%$. The aftereffect of green manure in severe dry years leads to an increase in the content of wet gluten in the grain of spring wheat.
\end{abstract}

\section{Introduction}

Determine the main trends in the yield and grain quality of spring (soft and durum) wheat in the conditions of Orenburg Cis-Urals.

The production of high-quality grain of spring wheat in the Russian Federation is an urgent present problem [1,2]. Grain quality is an indicator of the intensification of grain production, integrating the interaction of a variety of agrotechnical measures and natural and climatic conditions of wheat cultivation $[3,4]$. The cereal and pasta industry of the Russian Federation is experiencing a shortage of high-quality grain raw materials, which necessitates the search for new ways of its stable production $[5,6,7]$. In the conditions of the Orenburg region, the weather conditions of the growing season are of great importance for the formation of high-quality grain of spring wheat. In years with the least amount of precipitation, a relatively low yield of cultivated plants is formed, but the quality indicators of grain increase $[8,9,10]$.

\footnotetext{
*Corresponding author: skorohodov.vitali1975@mail.ru
} 
A good moisture supply of the growing season with the use of nitrogen and phosphorus fertilizers has a positive effect on the nature of grain and vitreousness. With a low level of mineral nutrition with a high removal of nutrients by a crop, a high supply of plants with moisture, the indicators of protein content and vitreousness of spring durum wheat grain decrease [11].

Embedding green manure in a seeded fallow increases the gluten content of durum wheat by $1.1 \%$ in comparison with that obtained as a result of the aftereffect of black fallow [12]. The optimal level of agricultural technology guarantees the receipt of raw materials for high-quality pasta from spring durum wheat.

\section{Methods}

The material for study of grain quality of spring (durum and soft) wheat was obtained as a result of a long-term experiment for 2016-2020 at a station with crop rotations and monocrops of agricultural crops in the department of agriculture and resource-saving technologies of the Federal State Budgetary Reasearch Institution of the Federal Research Centre for Biological Systems and Agricultural Technologies of the Russian Academy of Sciences. The coordinates of the location of the test site is $55.306547^{\circ} \mathrm{E} 51.775125^{\circ} \mathrm{N}$. The experiment was carried out on southern carbonate chernozems of medium-thick heavy loamy composition, with a humus content in the upper $(0-30 \mathrm{~cm})$ layer from 3.2 to $4.0 \%$. The content of total nitrogen in the stationary area was $0.20-0.31 \%$, available phosphorus was 0.14 $0.22 \%$, exchangeable potassium was up to $40 \% \mathrm{mg}$ per $100 \mathrm{~g}$ of soil. The reaction of soil solution had a neutral (7.0) to slightly alkaline (8.1) medium. The object of study was durum and soft spring wheat cultivated in six-field, two-field crop rotations and monoculture. The experiment was carried out according to two nutrient statuses (fertilized and unfertilized) using the following options:

1. Spring durum wheat over winter rye, for black and green manure fallow in six-field crop rotation;

2. Spring durum wheat over soft wheat in two-field crop rotation;

3. Spring soft wheat over durum wheat in the third field of six-field crop rotations in the after-action of various (black, green manure) types of fallow;

4. Spring soft wheat in the fifth field of a six-field crop rotation for peas and corn;

5. Spring soft wheat over durum wheat in two-field crop rotation;

6. Permanent sowing of spring soft wheat.

In the experiment, mineral fertilizers were used at a dose of $\mathrm{N}_{40} \mathrm{P}_{80} \mathrm{~K}_{40} \mathrm{~kg}$ of active ingredient per hectare.

The dimensions of the experimental plots, taking into account the use of fertilizers, are $3.6 \times 30 \mathrm{~m}$, without fertilizers, 3.6x60 m. The harvesting of spring (hard and soft) wheat was carried out by the Sampo-500 selection harvester.

The yield was determined taking into account the conversion to $14 \%$ humidity and $100 \%$ physical purity. The technology of cultivation and agricultural technology of spring wheat was adopted for the central zone of the Orenburg region. In the experiment, the following varieties were sown: durum wheat Orenburg 21, soft wheat Uchitel.

\section{Results}

Predecessor species, nutrient status, weather conditions of the growing season to a greater extent affect the formation of grain quality of spring wheat.

The weather conditions of the growing season have a significant impact on the quality of grain. In favorable years, the formation of wheat grain with a high quality of gluten $(28 \%$ 
or more) is facilitated by a higher temperature regime of the air and low moisture. With insufficient moisture, the weight of 1000 seeds decreases, but the protein in the wheat grain increases. High humidity increases the amount of gluten, but decreases its quality and vitreousness.

The amount of precipitation in 2016 amounted to $86 \mathrm{~mm}$ (44.5\% of the standard) with an average daily air temperature of $21^{\circ}$ higher than the average long-term indicator by $1.9^{\circ} \mathrm{C}$. The year was characterized as very dry, with the hydrothermal index of the growing season 0.38 units with 84 dry wind days. Vegetation period 2017 had average arid (GTC $0.50)$ precipitation for the period below the standard by $45 \mathrm{~mm}(110 \mathrm{~mm})$, the temperature exceeded the average annual temperature by $0.5^{\circ} \mathrm{C}$. In $2018,104 \mathrm{~mm}$ of precipitation fell ( $67 \%$ of the average annual indicators); the air temperature was recorded below the average annual by $1.4^{\circ} \mathrm{C}$. The number of dry wind days during the growing season was 4 , hydrothermal index was 0.39 units. The average daily air temperature in 2019 exceeded the standard by $1.1^{\circ} \mathrm{C}$. The number of dry wind days was 82 . During the growing season, precipitation fell by $13 \mathrm{~mm}$ more than the average annual standard.

The growing season of 2020 was very dry, the hydrothermal index amounted to 0.30 units. Sharp changes in air temperature during the growing season brought cultivated plants into a state of stress, reducing the quality of wheat grain. The predecessors had a great influence on the quality of wheat grain, the best among which are black fallow, fallow winter crops, corn and peas. A decrease in the quality of grain occurs in mono-crops of wheat without the use of mineral fertilizers. With a high yield of preceding winter crops and corn, which carry a large amount of nutrients, it is necessary to apply mineral fertilizers, and above all nitrogen fertilizers, to improve the quality of durum wheat. Nitrogen fertilizers always increase the protein and gluten content by (2.4-4.7\%) [18]. In years with abundant soil moisture, in cool spring and summer, bioprocesses in it slow down, leading to an acute nitrogen deficiency, which makes it necessary to add additional nitrogen fertilizers. The most effective means of obtaining high-quality wheat grain is to cultivate it in clean and busy fallows using fertilizers. The use of green green manure, according to many researchers, increases the quality indicators of durum wheat grain. In the experiment of A.V. Boryakova and others $[19,20,21]$, the amount of wet gluten in the aftereffect of black fallow was $32.9 \%$, and in the aftereffect of green manure occupied by sweet clover $34.0 \%$. This fact was also registered in our experiments.

The years of research, based on the air temperature and precipitation during the growing season, refer to medium arid (2017) and highly arid (dry 2016, 2018, 2019, 2020). The grain quality of spring soft wheat has some differences when formed in different dryness years. The baking qualities of spring soft wheat were determined in the years of average dryness (Table 1). Because of the shrunken grain, bread was not baked in dry years. The predecessors and nutrients status directly influenced the strength of flour and the content of raw gluten in the grain. Peas cultivated in a six-pole crop rotation against a normal background of $287 \mathrm{~J}$, against a background of fertilization of $325 \mathrm{~J}$ were the best among the predecessors of soft wheat, it had a positive effect on baking qualities (flour strength, J), it was assessed as good. A good predecessor for the indicator strength of spring soft wheat flour was spring durum wheat when cultivated in a two-field crop rotation, respectively, on a fertilized background of $285 \mathrm{~J}$., on an unfertilized background of $281 \mathrm{~J}$., with a satisfactory bakery rating. The worst among the predecessors of spring soft wheat in terms of baking qualities is its monocropping with flour strength indicators of 262 and $263 \mathrm{~J}$ on fertilized and unfertilized backgrounds, respectively. The indicator of the content of crude gluten in the grain of spring soft wheat depends primarily on weather factors. In dry years, its percentage is higher. The best predecessor of soft wheat in terms of wet gluten content in very dry years is maize for silage cultivated in a six-pole crop rotation. The smallest amount of gluten in the grain of common wheat is formed in dry years during mono-cultivation of 
crops (40\%), regardless of the nutritional background. In medium-dry years, the content of gluten in the grain of soft wheat according to the predecessor peas in a six-pole crop rotation was 35\% against a fertilized background and 34\% against an unfertilized background. In dry years, the percentage of gluten-wine on the same variant was $41 \%$ on two backgrounds. In the aftereffect of corn on silage in a six-pole crop rotation, the highest percentage of wet gluten $(42 \%)$ is observed in very dry years. During the years of research, the grain quality group corresponded to the II-nd and did not depend on the predecessor, nutritional background and weather conditions of the growing season.

Table 1. Grain quality of soft wheat and dependence on the type of predecessor, nutrient status and weather conditions, on average for 2016-2020.

\begin{tabular}{|c|c|c|c|c|c|c|c|c|}
\hline \multirow{5}{*}{ Indicators } & \multicolumn{8}{|c|}{ Type of predecessor } \\
\hline & \multicolumn{4}{|c|}{ 6-field rotation } & \multirow{2}{*}{\multicolumn{2}{|c|}{$\begin{array}{c}\text { 2-field rotation } \\
\text { Durum wheat }\end{array}$}} & \multirow{2}{*}{\multicolumn{2}{|c|}{$\begin{array}{c}\text { Monocropping } \\
\text { Soft wheat } \\
\end{array}$}} \\
\hline & \multicolumn{2}{|c|}{ peas } & \multicolumn{2}{|c|}{ corn } & & & & \\
\hline & & & & & $\mathbf{r} \quad \mathbf{s}$ & & & \\
\hline & medium & dry & medium & dry & medium & dry & medium & dry \\
\hline Energy of flour, J & $\frac{325}{287}$ & -* & $\frac{277}{284}$ & - & $\frac{285}{281}$ & $-j$ & $\frac{262}{263}$ & - \\
\hline $\begin{array}{l}\text { Bread scoring, } \\
\text { score }\end{array}$ & $\begin{array}{l}\text { good } \\
\text { good }\end{array}$ & $-*$ & $\begin{array}{l}\text { satisfatory } \\
\text { satisfatory }\end{array}$ & - & $\begin{array}{l}\text { satisfatory } \\
\text { satisfatory }\end{array}$ & - & $\begin{array}{l}\text { satisfatory } \\
\text { satisfatory }\end{array}$ & - \\
\hline $\begin{array}{l}\text { Crude gluten } \\
\text { content, } \%\end{array}$ & $\frac{35}{34}$ & $\frac{41}{41}$ & $\frac{36}{36}$ & $\frac{42}{42}$ & $\frac{34}{34}$ & $\frac{41}{39}$ & $\frac{36}{35}$ & $\frac{40}{40}$ \\
\hline $\begin{array}{l}\text { Gluten deformation } \\
\text { index-1, units }\end{array}$ & $\frac{100}{96}$ & $\frac{100}{88}$ & $\frac{98}{98}$ & $\frac{92}{92}$ & $\frac{67}{69}$ & $\frac{105}{100}$ & $\frac{98}{98}$ & $\frac{105}{98}$ \\
\hline Quality group & $\frac{\text { II }}{\text { II }}$ & $\frac{\mathrm{II}}{\mathrm{II}}$ & $\frac{\text { II }}{\text { II }}$ & $\frac{\text { II }}{\text { II }}$ & $\frac{\text { II }}{\text { II }}$ & $\underline{\mathrm{II}}$ & $\frac{\text { II }}{\text { II }}$ & $\frac{\text { II }}{\text { II }}$ \\
\hline
\end{tabular}

Note: above the line is fertilized background, below the line is not fertilized

* In dry years, bread was not baked due to the shrunken grain.

The percentage of wet gluten in grain of spring durum wheat increases in dry years (Table 2). The best predecessor for spring durum wheat with a high gluten content is black fallow in a six-pole rotation. In medium-dry years, this indicator was $37.5 \%$ against a fertilized background, 35.8\% against an unfertilized background, in dry years 34.0 and $31.0 \%$, respectively, in terms of backgrounds.

Table 2. Grain quality of durum wheat, depending on the type of predecessor, nutrition background and weather conditions.

\begin{tabular}{|c|c|c|c|c|c|c|}
\hline \multirow{4}{*}{ Indicators } & \multicolumn{6}{|c|}{ Predecessors } \\
\hline & \multicolumn{4}{|c|}{ 6-field rotation } & \multirow{2}{*}{\multicolumn{2}{|c|}{$\begin{array}{c}\text { 2-field rotation } \\
\text { Soft wheat }\end{array}$}} \\
\hline & \multicolumn{2}{|c|}{ Winter rye } & \multicolumn{2}{|c|}{ Black fallow } & & \\
\hline & $\begin{array}{c}\text { Me- } \\
\text { di- } \\
\text { um* }\end{array}$ & Dry* & $\begin{array}{l}\text { medi- } \\
\text { um }\end{array}$ & dry & $\begin{array}{l}\text { medi- } \\
\text { um }\end{array}$ & dry \\
\hline$C$ nudoluten content 0 & $\underline{33,8}$ & 32,0 & 37,5 & 34,0 & 33,2 & $\underline{34,0}$ \\
\hline Crude gluten content, $\%$ & $\overline{32,8}$ & $\overline{29,0}$ & $\overline{35,8}$ & $\overline{31,0}$ & $\overline{31,2}$ & $\overline{30,0}$ \\
\hline Gluten deformation index-1, & $\frac{106}{106}$ & $\frac{92}{92}$ & $\frac{108}{108}$ & $\frac{100}{102}$ & $\frac{108}{109}$ & $\frac{105}{102}$ \\
\hline Quality group & $\underline{\mathrm{II}}$ & $\underline{\text { II }}$ & $\underline{\mathrm{II}}$ & $\underline{\mathrm{II}}$ & $\underline{\mathrm{II}}$ & $\underline{\mathrm{II}}$ \\
\hline Characteristics of gluten & $\begin{array}{l}\frac{\text { satisfa }}{\text { tory }} \\
\text { satisfa } \\
\text { tory }\end{array}$ & $\begin{array}{l}\frac{\text { satisfat }}{\text { ory }} \\
\text { satisfat } \\
\text { ory }\end{array}$ & $\begin{array}{l}\frac{\text { satisfato }}{\text { ry }} \\
\text { satisfato } \\
\text { ry }\end{array}$ & $\begin{array}{l}\frac{\text { satisfato }}{\text { ry }} \\
\text { satisfato } \\
\text { ry }\end{array}$ & $\begin{array}{l}\frac{\text { unsatisfa }}{\text { tory }} \\
\text { Hunsatisf } \\
\text { atory }\end{array}$ & $\begin{array}{c}\text { unsatisfa } \\
\begin{array}{c}\text { tory } \\
\text { unsatisfa } \\
\text { tory }\end{array}\end{array}$ \\
\hline
\end{tabular}


Note: above the line is fertilized background, below the line is unfertilized, medium * medium arid years, dry* - dry years.

As can be seen from Table 2, the effectiveness of mineral fertilizers is influenced by the weather conditions of the growing seasons; in severely arid years, the effect of them is minimal.

In years with severe aridity, an increase in the content of crude gluten in durum wheat grain was registered in the aftereffect of both green manure and pure fallow. This is because these predecessors leave behind a soil better supplied with elements and moisture (Table. 3).

Table 3. Influence of different types of fallow on the quality of durum wheat grain.

\begin{tabular}{|c|c|c|c|}
\hline Predecessor fallow & Experimental years & $\begin{array}{c}\text { Raw gluten content } \\
\text { in grain, \% }\end{array}$ & $\begin{array}{c}\text { Gluten defor- } \\
\text { mation index-1 } \\
\text { Quality group }\end{array}$ \\
\hline \multirow{3}{*}{ Black } & 2016 & 35 & 100 \\
& 2017 & 33 & 105 \\
& 2018 & 32 & 110 \\
& 2019 & 34 & 115 \\
& 2020 & 33 & 105 \\
\hline \multirow{3}{*}{ Green } & 2016 & 36 & 105 \\
& 2017 & 35 & 115 \\
& 2018 & 33 & 105 \\
\hline
\end{tabular}

During the years of the experiment, the same effect of green manuring on quality group (II and III) is noted and it does not depend on the type of fallow. One of important quality indicators of durum wheat is pasta properties (Table 4).

Table 4. Pasta properties of durum wheat grain depending on the type of fallow.

\begin{tabular}{|c|c|c|c|c|c|c|}
\hline \multirow{2}{*}{$\begin{array}{c}\text { Experimental } \\
\text { years }\end{array}$} & \multicolumn{2}{|c|}{ Indicators } \\
\cline { 2 - 7 } & Strength & \multicolumn{2}{c|}{ Development rate } & \multicolumn{2}{c|}{ Total assessment } \\
\cline { 2 - 7 } & A & B & A & B & A & B \\
\hline 2016 & 380 & 410 & 3,8 & 4,2 & 3,3 & 4,2 \\
2017 & 420 & 520 & 4,1 & 3,7 & 3,0 & 3,0 \\
2018 & 450 & 500 & 4,0 & 4,2 & 4,2 & 3,6 \\
2019 & 510 & 550 & 4,2 & 4,1 & 4,0 & 4,0 \\
2020 & 400 & 430 & 3,8 & 4,0 & 3,7 & 3,6 \\
\hline Average value & 432 & 482 & 4,0 & 4,0 & 3,6 & 3,7 \\
\hline
\end{tabular}

Note: The color of pasta is creamy over the years.

A - for a black fallow, B - for a green manure.

In 2016 and 2017, the use of green manure improved the overall assessment of pasta properties and increased the fracture strength of the pasta. The general assessment of the properties of durum wheat pasta in the aftereffect of black and green fallow is practically the same. On average, over the five years of the experiment, the studied variants did not have a significant effect on the chemical composition of durum wheat grain and pasta properties. The use of green manure in a six-field crop rotation system is not limited to the effect on the yield of durum wheat. Their aftereffect on the quality of soft wheat grain is important (Table 5).

Table 5. Chemical composition of soft wheat grain in the aftereffect of black and green fallow, $\%$ of dry matter. 


\begin{tabular}{|l|c|c|c|c|c|c|c|c|}
\hline & $\mathbf{2 0 1 6}$ & $\mathbf{2 0 1 7}$ & $\mathbf{2 0 1 8}$ & $\mathbf{2 0 1 9}$ & $\mathbf{2 0 2 0}$ & \multicolumn{2}{|c|}{ value } & \multicolumn{2}{|c|}{} \\
\hline \multirow{2}{*}{ Total nitrogen } & 2,87 & 2,64 & 1,90 & 2,76 & 2,60 & 2,55 & 0,48 & \multirow{2}{*}{0,25} \\
& 2,75 & 2,68 & 2,14 & 2,51 & 2,75 & 2,56 & 0,32 & \\
\hline \multirow{2}{*}{ Crude protein } & 16,36 & 15,02 & 11,08 & 14,10 & 13,07 & 13,92 & 2,51 & \multirow{2}{*}{1,90} \\
& 15,68 & 15,05 & 13,06 & 14,18 & 16,01 & 14,80 & 1,50 & \multirow{2}{*}{ Phosphorus } \\
Potassium & 0,82 & 0,56 & 0,67 & 0,74 & 0,68 & 0,69 & 0,12 & \multirow{2}{*}{0,65} \\
& 0,77 & 0,64 & 0,72 & 0,78 & 0,67 & 0,72 & 0,08 & \\
& 0,43 & 0,40 & 0,42 & 0,43 & 0,38 & 0,38 & 0,03 & \multirow{2}{*}{0,03} \\
\hline
\end{tabular}

Note: above line is for black fallow, under the line is for a green manure.

The grain of soft wheat in the years under study was of low quality, the quality group in the aftermath of black and seeded fallow did not exceed II with the characteristic satisfactorily weak. Analyzing the indicators of the chemical composition of grain it was found that green manure increases the total nitrogen content by $0.03 \%$, crude protein by $0.16 \%$, phosphorus by $0.04 \%$.

\section{Discussion}

Natural and climatic conditions of Orenburg region contribute to the formation of highquality grain. In Orenburg Trans-Urals, one fourth of the volume of produced grain products of the 1st and 2nd classes of the Orenburg region is formed, and over $80 \%$ of spring durum wheat is supplied to the Russian market $[13,14,15]$. Durum wheat grain has the most valuable quality indicators and contains $1 \%$ more protein than soft wheat [16].

Many scientists consider the introduction of organic fertilizers into fallow and the damming of green manure as a way of increasing soil nitrogen and gluten in the grain of durum wheat [17].

Nitrogen fertilizers always increase the protein and gluten content by (2.4-4.7\%) [18]. In years with abundant soil moisture, in cool spring and summer, bioprocesses in it slow down, leading to an acute deficit of nitrogen, which makes it necessary to apply additional nitrogen fertilizers. The most effective means of obtaining high-quality wheat grain is to cultivate it in clean and busy fallows using fertilizers. The use of green green manure, according to many researchers, increases the quality indicators of durum wheat grain. In the experiment, A.V. Boryakova and others $[19,20,21]$, the amount of wet gluten in the aftereffect of black steam was $32.9 \%$, and in the aftereffect of green manure occupied by sweet clover was $34.0 \%$. This circumstance was also recorded in our experiments.

\section{Conclusion}

Various types of fallow do not have a significant effect on baking qualities of spring soft wheat, although a slight increase in certain indicators is noted for black fallow.

1. The content of wet gluten over the years of the experiment on two backgrounds in the aftereffect of black and green manure vapors is the same. The use of mineral fertilizers contributes to an increase in this indicator in all variants, but the effect of them is minimal, especially in dry years.

2. The quality of the grain of durum wheat depends on the weather conditions of the growing season and in years with abundant precipitation, it forms grain of poor quality, and in dry years with a low level of productivity, wheat has the best indicators. Fallow predecessors in the aftereffect influence on the grain quality of soft wheat. 


\section{References}

1. M.G. Evdokimov, V.S., Yusov, I.V. Pakhotina, Vestnik Kras. GAU, 4 (2021)

2. S.B. Mariem, J. González-Torralba, C. Collar et al., Plants (Basel), 9, 12 (2020)

3. T. A. Girma, A. Shaukat, S.S. Jagdeep et al., Front Plant Sci., 9 (2018)

4. S. Alahmad, Y. Kang, E. Dinglasan et al., Int. J. Mol. Sci., 21, 15 (2020)

5. P. Sangines de Carcer, S. Sinadj, M. Santonia, D. Fossati, B. Jeangros et al., Soil and Tillage Rescarch, 190 (2019)

6. S.A. Bakhvalova, A.V. Fedorova, Fertility, 119, 2 (2021)

7. N.A. Maksyutov, V.M. Zhdanov, V.Yu. Skorokhodov, Zemledeliye, 7 (2005)

8. N.N. Zezin, V.A. Vorobiev, A.V. Vorobiev, A.V. Bezgodov, Zernovoe khozyaystvo Rossii, 59, 5 (2018)

9. A.V. Titarenko, L.P. Titarenko, A.A. Kozlov, N.S. Vertiy, Grain economy of Russia, 59, 5 (2018)

10. A.P. Toygildin, M.I. Podsevalov, D.E. Ayupov, Bulletin of the Ulyanovsk State Agricultural Academy, 48, 2 (2019)

11. T. Mahmoudi, M.R. Oveisi, B. Jannat et al., African Jornal of Food Science, 9, 11 (2015)

12. A.A. Zavalin, O.A. Sokolov, Fertility, 1 (2018)

13. L.V. Galaktionova, T.N. Vasilieva, D.V. Mitrofanov, V.Yu Skorokhodov, S.V. Lebedev, IOP Conference Series: Earth and Environmental Science, 579 (2020)

14. V.Yu. Skorokhodov, N.A. Maksyutov, D.V. Mitrofanov, G.F. Yartsev, Yu.V. Kaftan, N.A. Zenkova, IOP Conference Series: Earth and Environmental Science (2021)

15. D.V. Mitrofanov, N.A. Maksyutov, V.Yu. Skorokhodov, Yu.V. Kaftan, L.V. Galaktionova, M.P. Mordvintsev, T.A. Tkacheva, IOP Conference series: Earth and environmental Science (2021)

16. S.G. Milher, M. Maccaferri, B.E. Huang, P. Mantovani, A. Massi, E. Frascaroli, R. Tiberosa, S. Salvi, Plant Biotechnology. J. (2015)

17. D.A. Kuznetsov, Agrarian scientific J., 11 (2020)

18. L.V. Yushkevich, A.G. Shchitov, I.V. Pakhotina, Agriculture, 1 (2019)

19. A. Andersson, L. Holm, Journal of Agronomy and Crop Science, 197 (2011)

20. A.J. Schlegel, Y. Assefa, C.R. Thompson, Agronomy Journal, 110, 1 (2018)

21. R.L. Cook, A. Trifica, Agronomy Journal, 108, 1 (2016) 